\title{
UJI COBA INSTRUMEN PENGKAJIAN KEPERAWATAN MEDIKAL BEDAH BERBASIS POLA FUNGSIONAL KESEHATAN GORDON
}

\author{
Aprilia Nuryanti* \\ *Prodi D III Keperawatan STIKES Dirgahayu Samarinda \\ Jl. Pasundan No. 21, Kelurahan Jawa, Samarinda Kode Pos 75122 \\ Email : aprilnuryanti@gmail.com
}

\begin{abstract}
ABSTRAK
Banyak teori yang digunakan dalam pengkajian keperawatan. Beberapa mengadopsi satu teori, yang lain menggabungkan beberapa teori. Fungsi Kesehatan Gordon memiliki 11 pola kehidupan manusia dan dapat menilai masalah atau kebutuhan perawatan pasien. Tujuan penelitian ini adalah untuk menguji kualitas instrumen pengkajian keperawatan dan kualitas dokumentasi yang digunakan mahasiswa saat bedah keperawatan medik dalam praktik klinis. Penelitian ini merupakan penelitian analitik pra eksperimental (one shot case study). Subjek dalam penelitian ini sebanyak 96 siswa untuk menilai kualitas instrumen pengkajian keperawatan dan 89 dokumen asuhan keperawatan yang ditulis oleh siswa tingkat III untuk menilai kualitas dokumentasi. Kuesioner skala likert dan daftar observasi digunakan. Penelitian dilaksanakan di STIKES Dirgahayu Samarinda dari bulan April sampai Juli 2019. Mutu dokumentasi pengkajian keperawatan sebagian besar dalam kategori baik. Beberapa komponen dalam kategori cukup yaitu akurasi pada riwayat kesehatan dahulu $(58,43 \%)$, kelengkapan pada kajian metabolik nutrisi $(75,28 \%)$, kajian pola aktivitas latihan $(75,28 \%)$, dan pemeriksaan fisik dimana tiga aspek dalam kategori cukup $(69,66 \%)$. Mutu instrumen dinilai dalam kategori baik pada ketiga aspek functionality, usability dan efficiency (>76\%). Pola fungsional kesehatan menurut Gordon sesuai untuk diterapkan dan dapat dikembangkan untuk pengkajian keperawatan yang baik.
\end{abstract}

Kata kunci: Instrumen pengkajian keperawatan, Mutu dokumentasi keperawatan, Pola fungsional kesehatan Gordon

\begin{abstract}
Many theories are used in the nursing assessment. Some adopt one theory, others combine several theories. Gordon's Health Functional had 11 patterns of human life and could assess patient's nursing problems or needs. Purpose this study was to test the quality of nursing assessment instrument and quality of documentations used by students when surgical medical nursing in clinical practice. This study was a pre-experimental analytic study (one shot case study). The subjects in this study were 96 students to assess the quality of nursing assessment instruments and 89 nursing care documents written by third-level students to assess the quality of documentation. Likert scale questionnaire and observation checklist are used. The study was conducted at STIKES Dirgahayu Samarinda from April to July 2019. The quality of nursing assessment documentation was mostly in the good category. Some components in the sufficient category were accuracy in past medical history (58.43\%), completeness in nutritional metabolic studies (75.28\%), exercise activity patterns (75.28\%). Physical examination was in the sufficient category (69.66\%). Instrument quality is rated in both categories on all three aspects of functionality, usability and efficiency (> 76\%). Gordon's Health Functional Patterns are suitable for application and can be developed for good nursing assessment.
\end{abstract}

Keywords: Nursing assessment instrument, Nursing documentation, Gordon's health functional patterns. 


\section{PENDAHULUAN}

Standar praktik keperawatan professional yang ditetapkan oleh Persatuan Perawat Nasional Indonesia (PPNI) mengacu pada proses keperawatan, terdiri dari lima tahap, yaitu pengkajian, diagnosis, perencanaan, implementasi dan evaluasi. Pengumpulan data dilakukan dengan cara wawancara, observasi, pemeriksaan fisik dan data penunjang klien (pemeriksaan laboratorium, rekam medis dan catatan lain). Sumber data didapatkan dari klien secara langsung, keluarga atau orang terkait dengan klien, tim kesehatan, rekam medis dan catatan lain. Data pengkajian yang dikumpulkan untuk mengenali status kesehatan klien saat ini, status kesehatan klien masa lalu, status fisiologis-psikologis-sosial-spiritual, respon terhadap terapi, harapan terhadap tingkat kesehatan yang optimal dan masalah-masalah risiko (PPNI, 2010). Banyak penelitian dilakukan untuk menilai kinerja asuhan keperawatan, dokumentasi keperawatan dan penerapan proses keperawatan di seting pelayanan rumah sakit. Sedangkan penelitian mengenai instrumen pengkajian yang dipelajari dan diterapkan oleh mahasiswa keperawatan masih sangat sedikit. Program Studi (Prodi) Diploma Tiga Keperawatan STIKES Dirgahayu Samarinda menerapkan kurikulum inti anjuran Asosiasi Institusi Pendidikan Vokasi Keperawatan Indonesia (AIPViKI) Tahun 2014 dan mata kuliah penciri lain dalam kurikulumnya (STIKES Dirgahayu, 2016). Kurikulum tersebut memuat mata kuliah Metodologi Keperawatan dan Dokumentasi Keperawatan. Pada mata kuliah Metodologi Keperawatan mahasiswa diajarkan teori berpikir kritis untuk melaksanakan pengkajian, penegakan diagnosis keperawatan, perencanaan, implementasi dan evaluasi. Mahasiswa dikenalkan pada kasus-kasus simulasi untuk dikaji demi mendapatkan masalah klien. Identifikasi yang baik melalui format pengkajian memberi gambaran mahasiswa mengenai apa saja yang perlu dikaji dalam diri seorang klien secara holistik. Mata kuliah Dokumentasi Keperawatan mengenalkan mahasiswa pada format-format umum yang digunakan untuk menuliskan proses keperawatan.

Banyak pendekatan dan teori yang digunakan dalam penyusunan format pengkajian. Ada yang mengadopsi dari satu teori, ada yang menggabungkan beberapa teori, misalnya 11 Pola Fungsional Kesehatan Gordon dan 6 Sistem (Nursalam, 2011). Pola Fungsional Kesehatan menurut Gordon memiliki seluruh aspek kehidupan manusia sebagai individu yang holistik. Oleh karena itu, secara umum teori ini dimanfaatkan untuk menyusun instrumen pengkajian klien untuk mendapatkan data pengkajian yang lengkap.

Studi sebelumnya menemukan bahwa ada mahasiswa yang masih mengalami kesulitan dalam meletakkan data yang diperoleh dari wawancara dan observasi pasien meskipun secara teoritis mereka telah mempelajari pola fungsional kesehatan menurut Gordon. Ada mahasiswa yang menyatakan lebih terbantu dengan pertanyaan pengkajian tertutup dibandingkan ketika mereka harus mengisi narasi hasil dari pertanyaan terbuka pada satu kajian. Beberapa kajian yang sulit dilakukan adalah 1) pola reproduksi-seksualitas karena merasa malu dan sulit menanyakannya kepada pasien serta takut menyinggung pasien, 2) pola hubungan-peran, 3) kajian konsep diripersepsi diri dan 4) kajian toleransi stresskoping lebih dirasa sesuai jika pasien 
mengalami masalah psikologis/ kejiwaan saja. Kurikulum menuntut mahasiswa kompeten dalam memenuhi kebutuhan manusia secara holistik (biologis, psikologis, sosial, kultural dan spiritual). Ini seringkali secara teknis dinilai terlalu rumit dan terlalu banyak kajian yang harus diisi (Nuryanti, 2018).

Mengembangkan

format

Pengkajian merupakan dasar utama melakukan asuhan keperawatan yang sesuai dengan kebutuhan klien, karena diagnosis keperawatan dirumuskan berdasarkan hasil pengkajian. Respon klien yang merupakan kebutuhan yang merupakan fokus dari asuhan keperawatan. Pengkajian yang benar, akurat, lengkap dan sesuai dengan fakta merupakan hal yang sangat penting (Nursalam, 2011).

Rekomendasi dari penelitian sebelumnya adalah perlu pengembangan format asuhan keperawatan sesuai hasil penelitian dan melakukan uji coba format pengembangan tersebut. Hal ini bertujuan untuk memudahkan mahasiswa dalam mencapai kompetensi dalam menggali data masalah keperawatan pada pasien. Bentuk format atau instrumen diharapkan membantu mahasiswa dalam melakukan pengkajian data-data fungsi kesehatan pasien menurut Pola Fungsional Kesehatan Gordon yang sudah memiliki bukti ilmiah efektifitasnya.

Tujuan penelitian ini adalah melakukan uji coba instrumen pengkajian keperawatan medikal bedah yang telah dikembangkan berdasar hasil penelitian sebelumnya. Dari penelitian dapat diketahui mutu instrumen pengkajian dan mutu dokumentasi pengkajian keperawatan berbasis Pola Fungsional Kesehatan menurut Gordon yang telah dikembangkan mulai bentuk format, penggunaan Bahasa, isi pertanyaan, model jawaban dan petunjuk pengkajian tiap pola kajian.

\section{BAHAN DAN METODE}

Peubah dalam penelitian ini adalah instrumen Pengkajian Keperawatan Medikal Bedah Berbasis Pola Gordon. Kajian 11 Pola Fungsional Kesehatan menurut Gordon, yaitu: 1) Pola Manajemen Kesehatan; 2) Pola Nutrisi dan Metabolik; 3) Pola Eliminasi; 4) Pola Aktivitas dan Latihan; 5) Pola IstirahatTidur; 6) Pola Persepsi Kognitif; 7) Kajian Konsep Diri-Persepsi Diri; 8) Pola Hubungan-Peran; 9) Pola Reproduksi dan Seksualitas; 10) Pola Toleransi terhadap Stres dan Koping dan 11) Pola Sistem Kepercayaan. Pola-pola ini disusun dalam bahasa, tata letak, isi, struktur, model jawaban dan petunjuk pengkajian yang digunakan untuk melakukan kajian 11 pola fumgsional kesehatan menurut Gordon. Instrumen ini dikembangkan berdasar penelitian sebelumnya Nuryanti (2018). Rancangan penelitian ini adalah penelitian analitik pra eksperimental (one shot case study) yang bertujuan menguji coba instrument sehingga diketahui mutu dokumentasi pengkajian keperawatan berdasar pola kesehatan menurut Gordon dan mutu instrumen pengkajian keperawatan berdasar fungsi, manfaat dan efisiensinya.

Subyek dalam penelitian ini ada dua jenis. Pertama adalah dokumen askep untuk dinilai mutu dokumentasi yang ditulis oleh mahasiswa. Kedua adalah mahasiswa tingkat III yang sedang praktik klinik KMB. Teknik sampling untuk dokumen asuhan keperawatan dengan teknik purposive sampling yang memenuhi kriteria yaitu kasus yang telah divalidasi dan dinilai oleh pembimbing. Berdasar 
kriteria maka sejumlah 89 dokumen diteliti.

Total sampling digunakan pada sub variable mutu instrumen pengkajian keperawatan. Terdapat 113 mahasiswa tingkat III yang sedang praktik KMB periode semester genap tahun akademik 2018/2019. Tidak seluruh mahasiswa mengisi kuesioner dikarenakan belum mendapatkan kasus sesuai target selama periode praktik sehingga 96 mahasiswa yang menjadi responden.

Kuesioner berjumlah 12 pertanyaan dengan skala Likert (1-4) digunakan untuk menilai mutu instrumen (fungsi, dayaguna, efisiensi). Lembar observasi dengan skala nominal (ya dan tidak) digunakan untuk menilai mutu dokumentasi pengkajian dari unsur kelengkapan, relevansi dan akurasi yang telah diuraikan dalam definisi operasional penelitian. Hasil observasi setiap komponen dokumentasi/pencatatan pengkajian dianalisa secara deskriptif dengan kategori baik (76-100\%), cukup $(56-75 \%)$ dan buruk $(<56 \%)$. Penelitian dilakukan di STIKES Dirgahayu Samarinda Kalimantan Timur dari bulan April sampai Juli 2019.

\section{HASIL PENELITIAN}

\section{Mutu Dokumentasi Pengkajian Keperawatan Medikal Bedah}

Mutu dokumen pengkajian keperawatan dinilai pada tiap kajian dari 11 pola fungsional kesehatan menurut Gordon. Pada setiap komponen terdapat beberapa pertanyaan pengkajian yang berupa pertanyaan terbuka dan tertutup. Pada pertanyaan terbuka, jawaban dalam bentuk isian singkat dan narasi. Pada pertanyaan tertutup jawaban berupa checklist maupun mencoret pilihan yang tidak sesuai.

Tabel 1. Mutu Dokumentasi Pengkajian KMB menurut Kelengkapan, Akurasi dan Relevansi oleh Mahasiswa Tingkat III STIKES Dirgahayu Samarinda $(n=89)$

\begin{tabular}{llll}
\hline No. & Komponen Pengkajian & Kategori & Freq.(\%) \\
\hline 1 & DATA DEMOGRAFI & Lengkap & $89(100 \%)$ \\
& & Akurat & $89(100 \%)$ \\
& & Relevan & $89(100 \%)$ \\
2 & RIWAYAT KEPERAWATAN & & \\
& a. keluhan utama MRS & Lengkap & $89(100 \%)$ \\
& & Akurat & $87(97,75 \%)$ \\
3 & b. keluhan utama saat pengkajian & Relevan & $89(100 \%)$ \\
& & Lengkap & $89(100 \%)$ \\
& & Akurat & $86(96,63 \%)$ \\
4 & RIWAYAT KESEHATAN & Relevan & $89(100 \%)$ \\
& a. riwayat kesehatan sekarang & & $88(98,88 \%)$ \\
& & Lengkap & $88(98,88 \%)$ \\
5 & b. riwayat kesehatan dahulu & Akurat & $89(100 \%)$ \\
& & Relevan & $88(98,88 \%)$ \\
& & Lengkap & $52(58,43 \%)$ \\
6 & c. riwayat kesehatan keluarga & Akurat & $86(96,63 \%)$ \\
& & Relevan & $87(97,75 \%)$ \\
& & Lengkap & $71(79,78 \%)$ \\
& & Akurat & $83(96,63 \%)$
\end{tabular}




\begin{tabular}{|c|c|c|c|}
\hline \multirow{3}{*}{7} & \multicolumn{3}{|l|}{ PENGKAJIAN POLA } \\
\hline & a. kajian manajemen kesehatan dan persepsi & Lengkap & $84(94,38 \%)$ \\
\hline & kesehatan & Akurat & $89(100 \%)$ \\
\hline & & Relevan & $88(98,88 \%)$ \\
\hline \multirow[t]{3}{*}{8} & b. kajian metabolik nutrisi & Lengkap & $67(75,28 \%)$ \\
\hline & b. kajian metabolik nutrisi & Akurat & $89(100 \%)$ \\
\hline & & Relevan & $89(100 \%)$ \\
\hline \multirow[t]{3}{*}{9} & c. kajian pola eliminasi & Lengkap & $81(91,01 \%)$ \\
\hline & & Akurat & $89(100 \%)$ \\
\hline & & Relevan & $89(100 \%)$ \\
\hline \multirow[t]{3}{*}{10} & d. kajian pola aktivitas-latihan & Lengkap & $67(75,28 \%)$ \\
\hline & & Akurat & $88(98,88 \%)$ \\
\hline & & Relevan & $87(97,75 \%)$ \\
\hline \multirow[t]{3}{*}{11} & e. kajian pola istirahat-tidur & Lengkap & $84(94,38 \%)$ \\
\hline & & Akurat & $88(98,88 \%)$ \\
\hline & & Relevan & $8898,88 \%)$ \\
\hline \multirow[t]{3}{*}{12} & f. kajian pola persepsi-kognitif & Lengkap & $87(97,75 \%)$ \\
\hline & & Akurat & $77(86,52 \%)$ \\
\hline & & Relevan & $82(92,13 \%)$ \\
\hline \multirow[t]{3}{*}{13} & g. kajian konsep diri-persepsi diri & Lengkap & $77(86,52 \%)$ \\
\hline & & Akurat & $89(100 \%)$ \\
\hline & & Relevan & $89(100 \%)$ \\
\hline \multirow[t]{3}{*}{14} & h. kajian pola hubungan-peran & Lengkap & $89(100 \%)$ \\
\hline & & Akurat & $89(100 \%)$ \\
\hline & & Relevan & $89(100 \%)$ \\
\hline \multirow[t]{3}{*}{15} & i. kajian pola reproduksi-seksualitas & Lengkap & $84(94,38 \%)$ \\
\hline & & Akurat & $85(95,51 \%)$ \\
\hline & & Relevan & $86(96,63 \%)$ \\
\hline \multirow[t]{3}{*}{16} & j. kajian pola toleransi terhadap stres-koping & Lengkap & $85(95,51 \%)$ \\
\hline & & Akurat & $87(97,75 \%)$ \\
\hline & & Relevan & $87(97,75 \%)$ \\
\hline \multirow[t]{3}{*}{17} & k. kajian pola sistem kepercayaan & Lengkap & $86(96,63 \%)$ \\
\hline & & Akurat & $87(97,75 \%)$ \\
\hline & & Relevan & $87(97,75 \%)$ \\
\hline \multirow[t]{3}{*}{18} & PEMERIKSAAN FISIK & Lengkap & $62(69,66 \%)$ \\
\hline & & Akurat & $62(69,66 \%)$ \\
\hline & & Relevan & $62(69,66 \%)$ \\
\hline
\end{tabular}

Dokumentasi pengkajian KMB menurut tabel 1 sebagian besar komponen pengkajian dalam kategori baik, namun ada beberapa dalam kategori cukup yaitu akurasi pada riwayat kesehatan dahulu (58,43\%), kelengkapan pada kajian metabolik nutrisi $(75,28 \%)$, kajian pola aktivitas latihan $(75,28 \%)$, dan pemeriksaan fisik dimana tiga aspek dalam kategori cukup $(69,66 \%)$.

\section{Mutu Instrumen Pengkajian Keperawatan Medikal Bedah}

Mutu instrumen pengkajian KMB dinilai menggunakan kuesioner yang diisi oleh 96 responden yaitu mahasiswa praktik klinik KMB yang memenuhi kriteria penelitian. 
Tabel 2. Mutu Instrumen Pengkajian KMB berbasis Pola Gordon ( $\mathrm{n}=96)$

\begin{tabular}{lll}
\hline Komponen & Nilai & Kategori \\
\hline A. Functionality & & \\
1. Menggambarkan kondisi pasien pada 11 kajian pola & 100 & Baik \\
2. Menggambarkan masalah keperawatan/ P (problem) & 80,99 & Baik \\
3. Mengidentifikasi respon pasien/ S (tanda dan gejala) & 80,73 & Baik \\
4. Mengidentifikasi penyebab/ E (etiologi) & 80,47 & Baik \\
B.Usability & & \\
1. Instrumen mudah dipahami & 79,69 & Baik \\
2. Tidak kesulitan dalam mengisi & 76,3 & Baik \\
3. Instrumen membantu identifikasi P, E, S & 81,25 & Baik \\
4. Mudah digunakan untuk menegakkan diagnosis keperawatan & 79,95 & Baik \\
C. Efficiency & & \\
1. Bentuk checklist dan paragraf efisien & 83,59 & Baik \\
2. Tiap pola kajian menunjukkan P & 78,91 & Baik \\
3. Cepat mengetahui masalah/ P & 78,91 & Baik \\
4. Efektif mengkaji seluruh aspek respon pasien & 79,17 & Baik \\
\hline
\end{tabular}

Hasil analisis deskriptif terhadap seluruh aspek penilaian mutu instrumen pengkajian KMB berbasis Pola Gordon yang dinilai oleh 96 orang responden menunjukkan hasil baik (>76\%). Penilaian terhadap fungsi instrumen dalam mengkaji data 11 kajian pola fungsional kesehatan menurut Gordon mendapatkan 100\% penilaian baik dari seluruh responden. Hal ini berarti dalam instrumen yang disusun dapat menggambarkan kebutuhan kajian masalah kesehatan yaitu pada kajian persepsi kesehatan/manajemen kesehatan, kajian pola nutrisi metabolik, eliminasi, aktivitas latihan, kognitif, istirahat tidur, persepsi diri, peran/ hubungan, seksualitas reproduksi, koping toleransi stress dan kepercayaan nilai.

\section{PEMBAHASAN}

Instrumen pengkajian yang digunakan mahasiswa dilengkapi dengan petunjuk pengisian sehingga mahasiswa dapat membacanya sebelum melakukan pengkajian ke pasien, namun pada faktanya mahasiswa seringkali tidak membawa lembaran petunjuk tersebut. Berdasarkan hasil penelitian (Nuryanti, 2018) mahasiswa menyatakan terbantu dengan daftar pertanyaan dan adanya kata kunci yang tertulis dalam instrumen pengkajian.

Pada pengkajian riwayat kesehatan dahulu sebagian besar responden hanya mengisi seputar penyakit yang sebelumnya pernah diderita pasien, sedangkan lingkup riwayat kesehatan ini bukan hanya riwayat penyakit dan opname saja namun termasuk kebiasaan yang mempengaruhi kesehatan pasien. Contohnya riwayat alergi, riwayat kecelakaan, dan riwayat penggunaan obat terkait penyakit atau lainnya. Standar Diagnosis Keperawatan Indonesia (SDKI) banyak kali mencatat perilaku yang menunjukkan riwayat kesehatan sebagai penyebab dan tanda mayor minor serta kondisi klinis terkait dari masalah keperawatan. Misalnya pada diagnosis ketidakpatuhan, perilaku tidak mengikuti program perawatan dan perilaku tidak menjalankan anjuran sebagai tanda obyektif mayor serta masalah kesehatan yang membutuhkan perubahan pola hidup sebagai kondisi klinis terkait dari diagnosis (PPNI, 2016).

Kelengkapan pada pengkajian metabolik nutrisi dan aktivitas latihan 
dalam kategori cukup. Komponen yang seringkali tidak diisi oleh mahasiswa adalah penghitungan indeks masa tubuh (IMT) dan keseimbangan cairan. IMT merupakan metode sederhana dan mudah dalam penghitungan status gizi seseorang. Pada standar diagnosis keperawatan Indonesia (SDKI) pada sub kategori nutrisi dan cairan, IMT ini sebagai tanda mayor dalam penegakan diagnosis seperti berat badan berlebih dan obesitas. Selain itu, komponen berat badan dan tinggi badan yang merupakan komponen penghitungan berat badan ideal, adalah tanda mayor obyektif pada diagnosis defisit nutrisi (PPNI, 2016). Penilaian status cairan dalam tubuh dilakukan dengan penghitungan keseimbangan cairan pada kajian pola nutrisi dalam pengkajian pola Gordon ini. Ketidaklengkapan data akan menyulitkan mahasiswa dalam menentukan data penunjang utama untuk penegakan diagnosis hipovolemia dan hipervolemia.

Pengkajian aktivitas latihan pada komponen aktivitas sebelum sakit tidak diisi yaitu pola waktu bekerja, pengkajian frekuensi olah raga (selama ... menit dan ... kali/minggu). Pola waktu bekerja penting untuk diketahui karena hal ini memengaruhi kebiasaan istirahat pasien, contohnya pasien yang berprofesi sebagai perawat akan memiliki pola waktu bekerja shif. Ketidaklengkapan data pengkajian pada komponen tersebut dapat menimbulkan kemungkinan kurangnya data fokus untuk merumuskan diagnosis keperawatan pada pola aktivitas dan latihan.

Pemeriksaan fisik merupakan satusatunya komponen pengkajian yang mempunyai nilai dalam kategori cukup pada aspek lengkap, akurat dan relevan. Pengetahuan dan keterampilan mahasiswa dalam melakukan pemeriksaan fisik ini akan menghasilkan data penunjang dalam merumuskan diagnosis keperawatan. Secara umum pemeriksaan fisik dilakukan dari kepala sampai ujung kaki (head to toe), dengan cara inspeksi, palpasi, auskultasi dan perkusi. Ketidaklengkapan pengkajian fisik ini dimungkinan karena penguasaan dan pengetahuan yang kurang dalam melakukannya. Penelitian lain menuliskan bahwa pengalaman klinis dan kesabaran dalam teknik melakukan pemeriksaan merupakan faktor yang sangat penting dalam ketrampilan pemeriaksaan fisik. Hasil pengkajian akan berbeda tergantung pada teknik pemeriksa. Penelitiannya menemukan bahwa faktor internal pada pemahaman sumber daya dan penggunaan literatur dari dosen sangat sedikit pada persentase 50,6\%. Di sisi lain, dari faktor eksternal tentang buku pedoman relatif lebih sedikit dengan prosentase 45,6\% (Pratiwi, 2012).

Kualitas dokumentasi keperawatan yang dilakukan perawat berhubungan secara signifikan dengan pendidikan perawat pada shif malam dan berhubungan signifikan dengan beban kerja perawat pada perawat shif pagi (Linda, 2018). Hal tersebut sejalan dengan kondisi mahasiswa saat praktik klinik KMB. Mahasiswa tidak hanya diberi tugas untuk menyusun askep kasus pasien namun juga memenuhi kompetensi yang dirancangkan dalam checklist keterampilan. Pada pagi hari, kegiatan perawatan yang komplek dan banyak mengharuskan mereka melakukan tindakan langsung ke pasien untuk mendapatkan nilai keterampilan. Pada saat mahasiswa dinas malam, mereka mempunyai lebih banyak waktu untuk menuliskan dokumentasi askep.

Türen, S., \& Enç, N. (2020) dalam penelitiannya melaporkan bahwa ada 
perbedaan yang signifikan antara kelompok kontrol dengan kelompok perlakuan yang dirawat dengan model pola fungsional kesehatan menurut Gordon. Penerapan model Gordon dalam asuhan keperawatan pasien gagal jantung dikaitkan dengan peningkatan kualitas hidup secara signifikan, dan mengurangi tingkat penerimaan kembali rumah sakit pada hari ke-30. Dengan demikian dapat disimpulkan bahwa kajian pola Gordon memiliki pengaruh yang baik dalam asuhan pasien.

Hasil skor rata-rata sikap dan keterampilan siswa dalam mengembangkan proses keperawatan menurut pola kesehatan fungsional Gordon pada kelompok perlakuan lebih besar dari kelompok kontrol. Disimpulkan bahwa model pola fungsional kesehatan Gordon dapat meningkatkan pembelajaran siswa dalam mengembangkan proses keperawatan (Mahnaz Khatiban, Shahin Tohidi, Maryam Shahdoust, 2019).

Untuk memudahkan mahasiswa dalam mengkaji masing-masing kajian disusun berupa checklist atau pertanyaan singkat atau daftar pertanyaan. Hal ini berdasarkan hasil penelitian sebelumnya, mahasiswa seringkali tidak mengisi kolom pengkajian karena kurangnya pengetahuan meskipun petunjuk pengisian sudah diberikan namun mahasiswa seringkali tidak membawa petunjuk pengisian format pengkajian.

Definisi instrumen adalah $a$ tool or implement, especially one for precision work; a measuring device used to gauge the level, position, speed, etc. of something; a formal or legal document. A tool or implement, especially one for delicate or scientific work; A thing used in pursuing an aim or policy; a means (Oxford Dictionaries online 2015). Definisi instrumen secara harafiah tersebut dapat diartikan alat (kata benda) atau melaksanakan (kata kerja), terutama untuk pekerjaan yang presisi; perangkat ukur yang digunakan untuk mengukur tingkat, posisi, kecepatan, dll dari sesuatu; dokumen resmi atau legal. Sebuah alat atau melaksanakan, terutama untuk pekerjaan halus atau ilmiah; hal digunakan dalam mengejar tujuan atau kebijakan; sarana. Kamus Besar Bahasa Indonesia (KBBI) menjelaskan bahwa instrumen adalah alat yang dipakai untuk mengerjakan sesuatu (seperti alat yang dipakai oleh pekerja teknik, alat-alat kedokteran, optik dan kimia) (Badan Pengembangan dan Pembinaan Bahasa, 2016). Definisidefinisi di atas dapat disimpulkan bahwa pengertian dari instrumen adalah alat atau sarana yang dipakai untuk mengukur tingkat dari suatu pekerjaan ilmiah, berupa dokumen resmi dan legal, dapat dijadikan sebagai sarana penelitian dan hasil pengumpulan datanya dijadikan sebagai bahan dalam mencapai tujuan atau kebijakan tertentu.

Instrumen pengkajian keperawatan diharapkan dapat menjadi alat atau sarana yang dipakai dalam mengukur, menilai, mengumpulkan data sebagai bahan untuk mencapai proses keperawatan. Dalam teori disebutkan bahwa saat pengkajian keperawatan perawat mengumpulkan data tentang status kesehatan klien secara sistematis, menyeluruh, akurat, singkat, dan berkesinambungan (PPNI, 2010).

Jika ditinjau dari aspek functionality (maka dapat disimpulkan bahwa instrumen pengkajian dalam penelitian ini memiliki mutu baik dalam mengkaji data masalah kesehatan pasien berdasarkan 11 pola fungsional kesehatan menurut Gordon. Aspek usability atau kemanfaatan instrumen untuk mencatat 
pengkajian keperawatan yang holistik, kelengkapan komponen pengkajian yang ada dalam instrumen, kemudahan dipahami dan kemudahan diisi, seluruh aspek dinilai dalam kategori baik. Efficiency adalah ketepatan daya guna format dokumentasi asuhan keperawatan sehingga dapat diisi dengan cepat dan tidak membuang tenaga bagi yang menggunakannya, dilihat dari unsur bentuk format dan efisiensi waktu dalam pengisian. Dengan bentuk pertanyaan berupa checklist atau daftar pertanyaan atau isian singkat membantu pengkajian yang dilakukan mahasiswa lebih efisien.

\section{KESIMPULAN DAN SARAN}

Simpulan

Mutu dokumentasi pengkajian keperawatan yang dinilai dengan lembar observasi skala nominal (ya) dan (tidak) menunjukkan hasil sebagian besar dalam kategori baik. Beberapa komponen dalam kategori cukup yaitu akurasi pada riwayat kesehatan dahulu, kelengkapan pada kajian metabolik nutrisi kajian pola aktivitas latihan dan pemeriksaan fisik dimana tiga aspek dalam kategori cukup. Mutu instrumen pengkajian keperawatan dinilai oleh responden menunjukkan hasil dalam kategori baik pada ketiga aspek functionality, usability dan efficiency.

\section{Saran}

Saran berdasar hasil penelitian ini, institusi pendidikan dapat memanfaatkan instrumen yang telah diteliti dan mengembangkannya untuk meningkatkan kemampuan dan keterampilan mahasiswa untuk melakukan proses keperawatan. Melakukan uji coba penerapan SDKI, SLKI dan SIKI (3S) seperti arahan dari PPNI dalam proses keperawatan menurut model fungsional kesehatan Gordon ini.

\section{KEPUSTAKAAN}

Badan Pengembangan dan Pembinaan Bahasa, K. P. d. K. R. I., 2016. Kamus Besar Bahasa Indonesia Daring. Jakarta: Kemendikbud Republik

Linda, S. E., 2018. Hubungan Antara Beban Kerja Dan Pendidikan Perawat Dengan Kualitas Dokumentasi Keperawatan Di Ruang Rawat Inap Rs Pelabuhan Jakarta Tahun 2001. Jurnal Kesehatan, pp. 22-40.

Mahnaz Khatiban, Shahin Tohidi, Maryam Shahdoust, 2019. The effects of applying an assessment form based on the health functional patterns on nursing student's attitude and skills in developing the nursing process. International journal of nursing sciences, pp. 329-333.

Nursalam, 2011. Proses dan Dokumentasi Keperawatan: Konsep dan Praktik Edisi 2. Jakarta: Salemba Medika.

Nuryanti, A., 2018. Evaluasi terhadap Instrumen Asuhan Keperawatan Medikal Bedah berbasis Pola Gordon di STIKES Dirgahayu Samarinda, Samarinda: STIKES Dirgahayu Samarinda.

PPNI, 2010. Standar Praktik Keperawatan. Jakarta: DPP PPNI.

PPNI, 2016. Standar Diagnosis Keperawatan Indonesia (SDKI). Jakarta: DPP PPNI.

Pratiwi, I. D., 2012. Identifikasi Faktor Pendukung Dan Faktor Penghambat Penguasaan Skill Pemeriksaan Fisik Pada Mahasiswa Program D-3 Keperawatan Universitas 
Muhammadiyah Malang. Saintika Medika.

STIKES Dirgahayu Samarinda, 2016. Kurikulum Program Studi Diploma Tiga Keperawatan STIKES Dirgahayu Samarinda. Samarinda: STIKES Dirgahayu Samarinda. 